\title{
A Flipped Classroom Approach to Supporting Game- Based Learning Activities for EFL Business Writing Course
}

\author{
Chi-Jen Lin \\ Graduate Institute of Digital Learning and Education \\ National Taiwan University of Science and Technology \\ Taipei, Taiwan \\ chi.jen1023@gmail.com
}

\author{
Gwo-Jen Hwang \\ Graduate Institute of Digital Learning and Education \\ National Taiwan University of Science and Technology \\ Taipei, Taiwan \\ gjhwang.academic@gmail.com
}

\begin{abstract}
English for specific purposes (ESP) such as English business writing is a challenging course for English as Foreign Language (EFL) learners. Not only is it related to English writing skills, but also to business knowledge. Context-game-based learning seems to be a good approach to situate EFL students in a meaningful and interesting practicing environment, as well as improve their learning motivation and interest. Nevertheless, researchers have indicated that, without effective learning strategies for helping students learn during their individual time or interacting with the teacher and peers, the effectiveness of game-based learning performance could be disappointing. To cope with this problem, this study proposes a flipped classroomoriented approach for supporting contextual game-based learning activities in an English business writing course. Moreover, an experiment has been conducted to evaluate the effectiveness of the approach on students' learning performance in a university-level English business writing class. As a consequence, it is concluded that the integrated flipped learning approach in the contextual game-based learning activity is helpful to motivate the students and learn more autonomously. In other words, the experimental results show that the flipped contextual game-based learning approach not only enhances the time involvement of the students' learning but also improves the English writing performance of the EFL students.
\end{abstract}

Keywords-flipped classroom, game-based learning, English for specific purposes (ESP)

\section{INTRODUCTION}

English is an important international language in the world [1], and people have been studying to master English skills in many countries. Compared to English native speakers, there are few opportunities for English as a foreign/second language (EFL) learners to practice language skills [2]. They often lack an authentic learning environment [3]. When learning in contexts related to real life, it would be easier for EFL learners to understand the meanings of the learning materials [2], and, if provided with more chances to practice in this environment, learners are likely to learn better [3].
However, it is not easy to provide real-life learning contexts for EFL learners. For example, Lan (2015) found that many EFL learners are too shy to use English in the real world. Educational digital games could solve this issue, as they are regarded as an effective way of engaging students in a study in situated learning environments (Sung, Hwang, \& Yen, 2015). Moreover, research indicates that digital games could provide authentic contexts for language or EFL learners (Hwang et al., 2016; Sung, Hwang, Lin, \& Hong, 2017). To date, an increasing number of researchers have reported that the contextual game-based learning approach is beneficial to EFL learners' learning performance [3] but mostly this approach has been conducted to facilitate students' vocabulary learning (Butler, 2015), listening, speaking Reinders \& Wattana, 2014), and reading (Sung et al., 2017). However, few studies have aimed to help students practice their writing skills (Allen, Crossley, Snow, \& McNamara, 2014), especially for business writing skills.

Business writing is a professional communication skill in the business and educational world. To master this writing skill, learners must gain knowledge of business processes, writing business letters, and so on. However, this knowledge is far beyond from university students' daily life, so understanding these de-contextualized learning contents could be difficult, and could even decrease students' learning interests and fail to engage them in meaningful learning. Given that contextual educational games could provide an appropriate learning environment for better learning (Sung et al., 2015), it would be useful to incorporate contextual gamebased learning into instructional activities for English business writing.

On the other hand, some researchers doubt the effectiveness of game-based learning in English classrooms. For instance, Bolliger, Mills, White, and Kohyama (2015) reported that some university students from Japan were concerned that games may not be an effective method for English language learning. Although contextual educational games could improve EFL students' learning motivation and engagement, and reduce their learning anxiety, it is still necessary to design learning activates to take advantage of the educational affordances of digital games. Allen et al. (2014) also indicated that, compared to instructing L1 writing, there is less effective 
guidance to support L2 students' writing. Moreover, compared to English writing, business writing is more challenging because its learning contents are less relevant to daily life. Therefore, it is necessary to develop effective learning strategies to integrate game-based learning into L2 business writing activities.

The flipped classroom is an innovative instructional approach which reverses the traditional teaching and learning pedagogy (Lai \& Hwang, 2016). Learners preview the online learning materials before the class, and do assignments or participate in the discussion or other activities in the class with the teacher's guidance (Bergmann \& Sams, 2015). Previous studies have stated the benefits of the flipped classroom approach. Teachers can have more opportunities to practice and apply what they have learned and provide required supports to individual students in the class [1]. For example, Thai, De Wever, and Valcke (2017) conducted a flipped classroom to help students on Invertebrates and found that the better improvement in learning performance and the process of learning contents in the online learning activities. Such a flipped learning approach that enables learners to have more practice time with peers and the teacher is quite suitable for English courses for EFL learners since teacher-supported practice, and peer interactions are important for language learning. Therefore, several researchers have attempted to conduct flipped classrooms for foreign language learning (Basal, 2015; Hung, 2015; Sung, 2015).

Therefore, in this study, a flipped classroom approach was integrated to support game-based learning activities and to enable learners to have more practice and peer-interaction time in the class. The experiment, with one undergraduate, flipped classroom was conducted at the university level in the northern part of Taiwan. This study aimed to investigate the participants' learning performance compared to the learners without flipped leering. The research question is: Do students who learn with the flipped game-based learning approach have significantly better English business writing performance than those who learned with game-based learning approach?

\section{LITERATURE REVIEW}

\section{A. Digital Game for English Learning}

The application of digital games has grown rapidly in school settings and various disciplines during the past decade, such as science, mathematics, language and art and so on (Hwang \& Wu, 2012). Digital game-based learning has been adopted as a pedagogically innovative learning approach to facilitate EFL learners' study (Cornillie, Thorne, \& Desmet, 2012). With the advancements in digital game technologies, and integrating digital game-based learning with learning theories or methods, many researchers have begun to explore its educational value in language instruction. For instance, Reinders and Wattana (2014) engaged Thai EFL learners in a university language course by playing an online contextual game and improved their willingness to communicate in English. Hwang et al. (2016) designed game-based learning activities integrated with meaningful learning materials from daily life to help senior high school students master English listening and speaking skills. Hwang, Hsu, Lai, and Hsueh (2017) designed a problem-based game for ninth-grade students' English listening and found that their learning performance, motivation, and engagement all improved. Moreover, Franciosi (2017) helped Japanese university students in EFL classes improve their vocabulary acquisition by learning in an online simulation game.

However, in a study conducted by Proske, Roscoe, and McNamara (2014), they designed a game-based learning activities to enhance German university students' ability to implement writing strategies in an English course. The gamebased practice did not outperform the conventional practice. The researchers concluded that without proper instructional support, educational games might not have the expected effect. Therefore, this study aimed to improve university students' learning performance by integrating a flipped classroom approach to supporting game-based learning activities for EFL business writing course.

\section{B. Flipped Classroom in English Language Teaching}

Bergman and Sams (2012) indicated that the flipped classroom is an instructional strategy that reverses the traditional lecture by delivering content to students via instructional videos before the class. In the meantime, it moves traditional after-class homework into the classroom. Students could engage in practicing or doing tasks with support from the teacher and peers. That is, the teacher has more opportunities to help students deal with problems (Findlay-Thompson \& Mombourquette, 2014). In addition, inclass flipped learning activities by using technologies, indepth discussions, peer evaluation, project-based learning, and game-based learning or gamification are appropriate learning strategies recommended by researchers (Lai \& Hwang, 2016).

In English instruction, writing is a critical part of English language teaching and is often assigned as homework (Bergmann \& Sams, 2015). In traditional writing classrooms, teachers sometimes spend time on explaining writing skills in class and limit the class time spent on the actual writing (Cockrum, 2014). Therefore, lacking sufficient practical opportunities for students in class is regarded as one crucial reason for unsuccessful English writing learning achievement. Over the past decade in higher education, flipped classroom approach have attempted to overcome these challenges by allocating more class time for learner's' active learning, enabling the teacher directly to engage students in the writing process by flipping the instructional method (Bergmann \& Sams, 2015).

Previous studies have provided the design of flipped classrooms and discussed the advantages and implementations for flipping English classes. For example, Engin (2014) designed a project to improve students' interest and experience of writing practice in the flipped classroom using a digital video tutorial followed by a model, research topic, and writing an assignment. The student-created videos promoted their English learning and encouraged more focus on writing and promoting accuracy in English. Sung (2015) also conducted a case study on a flipped classroom in an EFL (English as a Foreign Language) course. The results showed that the flipped. 
Classroom approach would create a better English language environment for students, despite the limitations of testoriented teaching. Therefore, in this study, we adopted a flipped classroom to help students use a contextual educational game in the writing context to improve their learning performance in a business writing classroom.

\section{METHOD}

In this study, we attempted to investigate the influence of a flipped classroom to supporting the game-based learning activities on students' English business writing performance.

\section{A. Flipped Game-Based Learning Activities}

In this study in the flipped classroom, an educational game was developed in an English business writing course. The researchers utilized RPG Maker VX from Enterbrain Incorporated to develop a contextual educational game. The story-based learning module is an essential part of the game, which is embedded with a game rules module designed by the course teacher based on business trade cycles or rules in real life. When students are engaged in playing the story-based learning activities, they experience the business trade rules, process, and culture. They could also have opportunities to learn knowledge about business trade, practicing e-mail sentences, and practicing business writing structure in a practice module. Moreover, they may visit the library to get help in the knowledge library module. On the other hand, teachers could manage the game rules module, knowledge library module, and practice module via the Teacher Interface module.

When a flipped classroom approach was designed in this study, the students learn with the game in the flipped classroom, they could access instructional learning materials, such as online video lectures, guiding questions, and written summaries provided by the course instructor, to help them more intentionally and meaningfully engage in the learning activities before class.

\section{B. Participants}

The study was designed in two English business writing classes, and they were assigned to an experimental group and a control group. A total of 68 students were enrolled in the two classes, which were taught by the same instructor. The experimental group of 35 students adopted the flipped gamebased learning approach, while the control group with 33 students adopted the game-based learning approach. The students in these two classes were undergraduates whose ages ranged from 18 to 22 .

\section{Data Collection}

We collected data from students' business letters. The level of the English business writing tests was determined by the English instructors in the Language Center at the University, and two English experts decided the writing topics and then assigned similar topics for the pre- and post-test, indicating that the level of difficulty of the two writing tests was the same. Within the semester, the students' two English business letters were uploaded to the learning management system.

\section{Rubric of English Business Writing Performance}

A rubric of English business writing performance modified by Texas Education Agency (2006) was administered. The rubric consists of four dimensions (i.e., organization, content, appearance, and language use) with a total score of 120 points, 30 points for each dimension. These four dimensions' measure how students accurately use a correct business letter format, how well they state the purpose of the letter, how well they explain the facts to support the main idea, whether their tone is appropriate for the intended audience, whether they could type and use correct spacing, font, and format, and whether they could accurately use punctuation and grammar.

\section{E. Experiment Procedure}

The English business writing courses were taught by the same instructor in 2016. The courses aimed to help the students understand the business knowledge, processes of business trade, and to facilitate their business letter structures and writing. Following shows the experimental procedure.

In the first week, the students took a pre-test of Inquiry Business letter. In the following eight weeks, the experimental group students in the flipped classroom were scheduled to watch instructional videos in English introducing the basic knowledge of the business trade, play the contextual game to experience the business trade procedure, and complete the writing summary sheet regarding the video before the class. As a consequence, extra activities and writing assignments were scheduled in the class with the assistance of the teachers and the peers. That is, by moving the lectures to the beforeclass time using the instructional videos, the teacher needed not give lectures to the experimental group students in the class, and hence had time to guide them to do the writing assignment or exercises and interact with them in the class.

On the other hand, the students in the control group learned with the conventional game-based learning approach; that is, they received the lectures that have the same content as the instructional videos for the experimental group, played the same game, and completed the learning sheets in the class. Moreover, they were asked to do the exercises and homework after the class. In the second to last week of the experiment, the participants took a post-test on writing an Inquiry Business letter.

\section{RESULT}

The students' English business writing pre-test and posttest were evaluated by two instructors who had years of experience teaching English writing courses. The Pearson Correlation values of the tests were $0.77(p<0.01)$ and 0.82 $(p<0.01)$, respectively. In order to examine the effect of the flipped game-based learning approach on business writing performance, compared to the conventional game-based learning approach, a one-way analysis of covariance (ANCOVA) was utilized with the pre-test scores as a covariate, the learning approaches as an independent variable, and the post-test scores as a dependent variable. 
After testing that the assumption of homogeneity of slopes was met with $F=0.117(p>.05)$, it was reasonable to conduct further analysis with ANCOVA. As indicated in Table I, there was a statistically significant difference between the two groups with $F=38.50\left(p<.001, \eta^{2}=0.372\right)$. Moreover, the adjusted mean of the experimental group was 96.56 with a standard deviation error of 1.06 , which was higher than the adjusted mean of the control group with 86.07 (Std. error $=1.09$ ). It was inferable that the flipped game-based learning approach outperformed the conventional game-based learning approach regarding facilitating students' business writing. Furthermore, the effect size, partial eta squared $\left(\eta^{2}\right)$ with a value of 0.14 , means a large effect, indicating that the benefit of the proposed learning approach was overwhelming due to $\eta^{2}=0.372$.

TABLE I: The ANCOVA results for business writing performance

\begin{tabular}{lcccllll}
\hline Group & N & Mean & SD & $\begin{array}{l}\text { Adjusted } \\
\text { mean }\end{array}$ & $\begin{array}{l}\text { Std. } \\
\text { error }\end{array}$ & $\boldsymbol{F}$ & $\boldsymbol{\eta}^{\mathbf{2}}$ \\
\hline $\begin{array}{l}\text { Experimental } \\
\text { group }\end{array}$ & 35 & 96.86 & 5.43 & 96.56 & 1.06 & $38.50^{* * *}$ & 0.372 \\
$\begin{array}{l}\text { Control } \\
\text { group }\end{array}$ & 33 & 85.76 & 5.45 & 86.07 & 1.09 & & \\
\hline Note. $^{* * *} p<.001$. & & & & & &
\end{tabular}

\section{DISCUSSION AND CONCLUSIONS}

The analysis results indicate that the flipped classroom approach to supporting game-based learning activities was effective in the English business writing classroom in terms of improving the students' business writing performances. According to the previous studies, we also gain support from the literature. For example, Chik (2014) and Hwang et al. (2016) indicated that contextual game-based language learning demonstrated significant potential for language classrooms from the aspects of enhancing learner performance, autonomy, and community. In addition, Blau and Shamir-Inbal (2017) indicated that flipping a conventional learning approach could further promote students' learning performance by enabling them to practice more before class as well as during the class time. Also, they could also have more opportunities to interact with peers and teachers and receive assistances from the teacher rather than practicing alone after the class.

To sum up, the flipped game-based learning approach offers an effective environment where students can better understand the contexts and knowledge of business trade as well as having more in-class time for practicing English business writing. On the other hand, there are several limitations to the present study. The proposed flipped gaming approach was only applied to a business English writing course in a university; the findings might not be able to represent the effectiveness of the same approach for other courses and subjects.

For future research, it would be worth investigating the impacts of flipped gaming approach on other English language teaching courses. It would also be interesting to investigate students' gaming behaviors, as well as their interactive behaviors in the classroom and online, could be valuable. Finally, further investigations into flipped game-based language learning in the writing classroom can provide a holistic picture of English language teaching development.

\section{ACKNOWLEDGMENT}

This study is supported in part by the Ministry of Science and Technology of the Republic of China under contract numbers MOST-105-2511-S-011-008-MY3 and MOST 1062511-S-011 -005 -MY3.

\section{REFERENCES}

[1] Hsieh, J. S. C., Wu, W. C. V., \& Marek, M. W. (2017). Using the flipped classroom to enhance EFL learning. Computer Assisted Language Learning, 30(1-2), 1-21.

[2] Shadiev, R., Hwang, W. Y., Huang, Y. M., \& Liu, C. J. (2016). Investigating applications of speech-to-text recognition technology for a face-to-face seminar to assist learning of non-native English-speaking participants. Technology Pedagogy and Education, 25(1), 119-134.

[3] Hwang, W. Y., \& Chen, H. S. L. (2013). Users' familiar situational contexts facilitate the practice of EFL in elementary schools with mobile devices. Computer Assisted Language Learning, 26(2), 101-125.

[4] Hwang, W. Y., Shih, T. K., Ma, Z. H., Shadiev, R., \& Chen, S. Y. (2016). Evaluating listening and speaking skills in a mobile game-based learning environment with situational contexts. Computer Assisted Language Learning, 29(4), 639-657.

[5] Lan, Y. J. (2015). Contextual EFL learning in a 3D virtual environment. Language Learning \& Technology, 19(2), 16-31.

[6] Sung, H. Y., Hwang, G. J., \& Yen, Y. F. (2015). Development of a contextual decision-making game for improving students' learning performance in a health education course. Computers \& Education, 82, 179-190.

[7] Sung, H. Y., Hwang, G. J., Lin, C. J., \& Hong, T. W. (2017). Experiencing the Analects of Confucius: An experiential game-based learning approach to promoting students' motivation and conception of learning. Computers \& Education, 110, 143-153.

[8] Butler, Y. G. (2015). The use of computer games as foreign language learning tasks for digital natives. System, 54, 91-102.

[9] Reinders, H., \& Wattana, S. (2014). Can I say something? The effects of digital game play on willingness to communicate. Language Learning \& Technology, 18(2), 101-123.

[10] Allen, L. K., Crossley, S. A., Snow, E. L., \& McNamara, D. S. (2014). L2 writing practice: game enjoyment as a key to engagement. Language Learning \& Technology, 18(2), 124-150.

[11] Bolliger, D. U., Mills, D., White, J., \& Kohyama, M. (2015). Japanese Students' Perceptions of Digital Game Use for English-Language Learning in Higher Education. Journal of Educational Computing Research, 53(3), 384-408.

[12] Lai, C. L., \& Hwang, G. J. (2016). A self-regulated flipped classroom approach to improving students' learning performance in a mathematics course. Computers \& Education, 100, 126-140.

[13] Bergmann, J., \& Sams, A. (2015). Flipped Learning for English Language Instruction. United States: International Society for Technology in Education.

[14] Thai, N. T. T., De Wever, B., \& Valcke, M. (2017). The impact of a flipped classroom design on learning performance in higher education: Looking for the best "blend" of lectures and guiding questions with feedback. Computers \& Education, 107, 113-126.

[15] Basal, A. (2015). The implementation of a flipped classroom in foreign language teaching. Turkish Online Journal of Distance Education, 16(4), 28-37.

[16] Hung, H. T. (2015). Flipping the classroom for English language learners to foster active learning. Computer Assisted Language Learning, 28(1), 81-96.

[17] Sung, K. (2015). A case study on a flipped classroom in an EFL content course. Multimedia-Assisted Language Learning, 18(2), 159-187. 
[18] Hwang, G. J., \& Wu, P. H. (2012). Advancements and trends in digital game-based learning research: a review of publications in selected journals from 2001 to 2010. British Journal of Educational Technology, 43(1), E6-E10.

[19] Cornillie, F., Thorne, S. L., \& Desmet, P. (2012). Digital games for language learning: challenges and opportunities. ReCALL, 24, 243-256.

[20] Hwang, G. J., Hsu, T. C., Lai, C. L., \& Hsueh, C. J. (2017). Interaction of problem-based gaming and learning anxiety in language students' English listening performance and progressive behavioral patterns. Computers \& Education, 106, 26-42.

[21] Franciosi, S. J. (2017). The Effect of Computer Game-Based Learning on FL Vocabulary Transferability. Educational Technology \& Society, 20(1), 123-133.

[22] Proske, A., Roscoe, R. D., \& McNamara, D. S. (2014). Game-based practice versus traditional practice in computer-based writing strategy training: effects on motivation and achievement. Educational Technology Research and Development, 62(5), 481-505.
[23] Bergmann, J., \& Sams, A. (2012). Flip your classroom: Reach every student in every class every day. Virginia: International Society for Technology in Education.

[24] Findlay-Thompson, S. \& Mombourquette, P. (2014). Evaluation of a Flipped Classroom in an Undergraduate Business Course. Business Education \& Accreditation, 6(1), 63-71.

[25] Cockrum, T. (2014). Flipping your English Class to Reach All Learners Strategy and Lesson Plans. United States: Graphics.

[26] Engin, M. (2014). Extending the flipped classroom model: Developing second language writing skills through student-created digital videos. Journal of the Scholarship of Teaching and Learning, 14(5), 12 - 26.

[27] Texas Education Agency. (2006). Rubric for Business Letter Writing. Retrieved from http://cte.sfasu.edu/wpcontent/uploads/2012/01/Letter.doc

[28] Chik, A. (2014). Digital gaming and language learning: Autonomy and community. Language Learning \& Technology 18(2), 85-100.

[29] Blau, I., \& Shamir-Inbal, T. (2017). Re-designed flipped learning model in an academic course: The role of co-creation and co-regulation. Computers \& Education, 115, 69-81. 